\title{
1-Deoxynojirimycin Derivatives from the Marine Sponge Lendenfeldia chondrodes
}

\author{
Ryuichi Sakai, Hisao Kamiya \\ Dedicated to the memory of Professor Kenneth L. Rinehart.
}

Received: May 30, 2006 / Accepted: August 15, 2006

(C) Japan Antibiotics Research Association

\begin{abstract}
Two 1-deoxynojirimycin derivatives, 1deoxynojirimycin-6-phosphate (1) and $\mathrm{N}$-methyl-1deoxynojirimycin-6-phosphate (2) were isolated from an aqueous extract of Micronesian marine sponge Lendenfeldia chondrodes for the first time as natural products. Structures of these compounds were assigned on the basis of their spectral data and chemical degradation.
\end{abstract}

Keywords deoxynojirimycin, $\alpha$-glucosidase inhibitor, marine sponge, Lendenfeldia

1-Deoxynojirimycin (dNM) is an iminosugar first isolated from Mori Cortex (dried root bark of mulberry tree, Morus spp.) [1]. dNM and its $N$-alkyl derivatives are potent inhibitors of $\alpha$-glucosidase [2], and this activity is purportedly responsible for their intriguing biological actions such as antiviral activity [3 6], impediment of HIV infection [7], inhibition of spermatogenesis [8]. Thus, not only dNM itself but also some $N$-alkylated dNM's are therapeutic candidates in the areas of hyperglycemia, AIDS, and Gaucher disease [9 14].

We have been conducting an extensive survey for structurally interesting bioactive amino acids and related compounds from aqueous extract of the Micronesian sponge, Lendenfeldia chondrodes (formally identified as Dysidea herbacea) collected in Yap, Micronesia since the discovery of novel excitatory amino acid dysiherbaine [15]. In the course of the study we have isolated neodysiherbaine

R. Sakai (Corresponding author), H. Kamiya: Kitasato University School of Fisheries Sciences, Sanriku-cho, Ofunato Iwate 022-0101, Japan, E-mail: r.sakai@kitasato-u.ac.jp
A [16], and several new betaines such as dysibetaine [17], dysibetaine PP, dysibetaine $\mathrm{CPa}$ and $\mathrm{CPb}$ [18], and demonstrated that this sponge is a rich source of novel amino acid derivatives of some biomedical interests. In this paper, we deal with isolation and structure elucidations of deoxynojirimycin derivatives: 1-deoxynojirimycin-6phosphate (1) and its $N$-methyl derivative (2) from this sponge. This is the first example of isolation of phosphates derivatives of deoxynojirimycin in nature.

A sample of $L$. chondrodes was collected in Yap, Micronesia at depth of $6 \sim 8 \mathrm{~m}$. The aqueous extract was separated by a series of gel filtration, anion exchange chromatographies, then finally by reversed-phase HPLC to afford compounds $\mathbf{1}$ and $\mathbf{2}$. In the anion exchange chromatography both $\mathbf{1}$ and $\mathbf{2}$ were eluted as a broad slope with acetic acid $(0.05 \mathrm{~N})$.

The ${ }^{1} \mathrm{H}$ NMR data for $\mathbf{1}$ were characteristics of highly oxygenated compound, in that all resonances were observed between $\delta 2.8$ and 4.1 for eight protons. In the ${ }^{13} \mathrm{C} \mathrm{NMR}$ spectrum six resonances were observed, but two of these signals, resonating at $\delta 59.4$ and 61.7 , were broad and split. A FABMS spectrum for 1 gave a molecular ion at $m / z 244$ $(\mathrm{M}+\mathrm{H})^{+}$. Since the high resolution FABMS analysis of the molecular ion, $m / z$ 244.0566, suggested a possible formula $\mathrm{C}_{6} \mathrm{H}_{14} \mathrm{NO}_{7} \mathrm{P}$ for $\mathbf{1}$, a ${ }^{31} \mathrm{P}$ NMR spectrum of $\mathbf{1}$ was measured that not only confirmed a presence of phosphorus atom but also assigned it as the phosphate group on the basis of chemical shift ( $\delta 3.14)$. The splitting of signals observed in the ${ }^{13} \mathrm{C}$ NMR, due to the $\mathrm{C}-\mathrm{P}$ coupling is consistent with these data. COSY data for $\mathbf{1}$ (Table 1) indicated a spin system as shown in Figure 1. Since the molecular formula of 1 requires one unsaturation, while no evidence for $s p^{2}$ carbon including carbonyl groups was observed in the NMR data, mono-cyclic structure of $\mathbf{1}$ was evident. The ${ }^{13} \mathrm{C}$ 
Table 1 NMR data for compounds 1 and $\mathbf{2}$

\begin{tabular}{|c|c|c|c|c|}
\hline \multirow{2}{*}{$\# C$} & \multicolumn{2}{|r|}{1} & \multicolumn{2}{|r|}{2} \\
\hline & ${ }^{13} C^{a}\left({ }^{31} P\right)$ & ${ }^{1} \mathrm{H}^{\mathrm{b}}$ & ${ }^{13} C^{c}\left({ }^{31} P\right)$ & ${ }^{1} \mathrm{H}^{\mathrm{d}}$ \\
\hline \multirow[t]{2}{*}{1} & 46.5 & $2.88, t, 12.8$ & 57.7 & $3.08 t, 12.4$ \\
\hline & & $3.42, \mathrm{~m}$ & & $3.46, \mathrm{dd}, 12.4,5.1$ \\
\hline 2 & 67.4 & 3.69, ddd, $11.5,9.2,5.1$ & 67.0 & 3.80, ddd, $11.7,9.5,5.1$ \\
\hline 3 & 76.6 & $3.42, \mathrm{~m}$ & 76.6 & $3.51, t, 9.5$ \\
\hline 4 & 67.9 & $3.55, \mathrm{dd}, 10.5,9.4$ & 67.7 & $3.74, t, 10.0$ \\
\hline 5 & $59.4, \mathrm{brd}, J_{\mathrm{cp}}=8.2$ & $3.25, \mathrm{brdt}, 10.5,3.5$ & $67.3 \mathrm{~d}, J_{\mathrm{cp}}=8.8$ & 3.16, br d, 10.0 \\
\hline \multirow[t]{2}{*}{6} & $61.7, \mathrm{~d}, J_{\mathrm{cp}}=4.5$ & $4.08, \mathrm{brm}$ & $58.2, d, J_{c p}=4.5$ & $4.20, \mathrm{ddd}, 13.0,4.5\left(J_{\mathrm{P}-\mathrm{H}}\right), 3.0$ \\
\hline & & & & $4.25, \mathrm{ddd}, 13.0,5.5\left(J_{\mathrm{P}_{-H}}\right), 2.0$ \\
\hline $\mathrm{CH}_{3}$ & & & 41.4 & $2.98, \mathrm{~s}$ \\
\hline $\mathrm{OPO}_{3}^{-}$ & (3.14) & & $(2.94)$ & \\
\hline
\end{tabular}

a Recorded at $100 \mathrm{MHz}$. ${ }^{\text {b Recorded at }} 400 \mathrm{MHz}$. ${ }^{\mathrm{c}}$ Recorded at $125 \mathrm{MHz}$. ${ }^{\mathrm{d}}$ Recorded at $500 \mathrm{MHz}$.

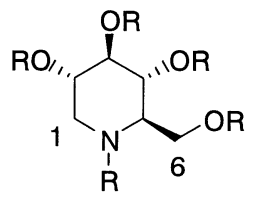

dNM: $\mathrm{R}=\mathrm{H}$

3: $\mathrm{R}=\mathrm{COCH}_{3}$

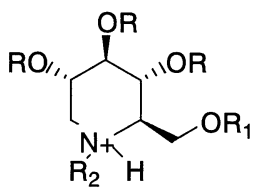

1: $\quad \mathrm{R}=\mathrm{H}, \mathrm{R}_{1}=\mathrm{PO}_{3^{-}}, \mathrm{R}_{2}=\mathrm{H}$

2: $\quad \mathrm{R}=\mathrm{H}, \mathrm{R}_{1}=\mathrm{PO}_{3^{-}}, \mathrm{R}_{2}=\mathrm{CH}_{3}$

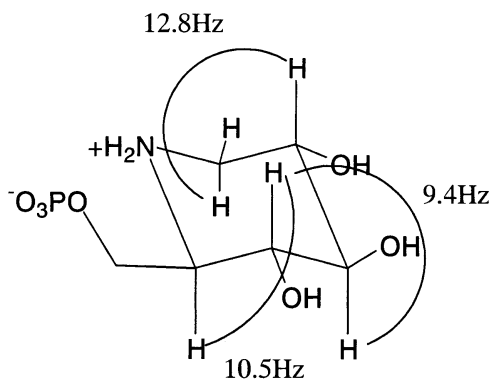

selected ${ }^{3} J_{H-H}$ values for 1

Fig. 1

NMR chemical shifts and HMBC correlations between H-5 and $\mathrm{C}-1$ readily assigned the 1-deoxyiminohexose structure for $\mathbf{1}$. The position of the phosphate group was assigned at C- 6 because irradiation of the phosphate signal in the ${ }^{31} \mathrm{P}$ NMR corrupted the ${ }^{1} \mathrm{H}$ signal at $\delta 4.08$ for $\mathrm{H}-6$. Additionally C-6 and C-5 were observed as split signals in the ${ }^{13} \mathrm{C}$ NMR. The ${ }^{3} J_{\mathrm{H}-\mathrm{H}}$ coupling analysis indicated that all the oxygen atoms in the piperidine ring oriented equatorially (Fig. 1). These data suggested that the structure of 1 was 1 -deoxynojirimycin-6-O-phosphate. A treatment of 1 with $6 \mathrm{~N} \mathrm{NaOH}$ followed by acetic anhydride in pyridine afforded peracetyl dNM (3). FABMS, ${ }^{1} \mathrm{H}$ NMR, and TLC data for $\mathbf{3}$ were identical with those derived from the authentic material, and additionally the CD spectrum gave the same sign and $\lambda$ ext as the authentic sample. We thus concluded that the absolute configuration of $\mathbf{1}$ is the same as that of dNM.

The molecular formula of compound $2, \mathrm{C}_{7} \mathrm{H}_{16} \mathrm{NO}_{7} \mathrm{P}$, was assigned on the basis of FABMS and ${ }^{13} \mathrm{C}$ NMR data. NMR for $\mathbf{2}$ shared very similar characteristics with those for $\mathbf{1}$ except for the presence of a methyl singlet at $\delta 2.98$ and corresponding ${ }^{13} \mathrm{C}$ signal at $\delta 41.4$ in 2 . Signal splitting in the ${ }^{13} \mathrm{C}$ NMR at $\delta 67.3$ due to the presence of phosphate group, was also observed. The phosphorus atom in $\mathbf{2}$ 
resonated at $\delta 2.94$ in the ${ }^{31} \mathrm{P}$ NMR spectrum, and an irradiation of the ${ }^{31} \mathrm{P}$ signal resulted in simplification of the ${ }^{1} \mathrm{H}$ signals for $\mathrm{CH}_{2}-6$. These data assigned the position of phosphate group at C-6. All the protons and carbons were assigned by two-dimensional NMR data. In the HMBC spectrum, cross peaks between the $\mathrm{N}-\mathrm{CH}_{3}$ protons and $\mathrm{C}-1$ and $\mathrm{C}-5$, confirmed the iminohexose carbon skeleton for $\mathbf{2}$. All those data were consistent with the structure of $\mathrm{N}$-methyl-1-deoxynojirimycin-6-O-phosphate (2).

A numbers of dNM and related compounds have been isolated from terrestrial plants $[19,20]$ as well as microorganisms [21, 22], however, to the best of our knowledge, this is the first example of isolation of dNM from marine organisms. Compounds 1 and 2, 1-phosphate derivatives of dNM have not previously been reported as natural products. Incidentally however, compounds $\mathbf{2}$ and its $\mathrm{N}$-butyl derivative have been prepared by enzymatic conversion of dNM with yeast hexokinase as prodrugs for a treatment of AIDS. In the $\alpha$-glucosidase inhibition assay, both dNM and 1 showed activity albeit with significant differences in potency with $K i$ value of 0.83 and $6600 \mu \mathrm{M}$, respectively [23].

\section{Experimental}

NMR data were recorded at either 400 , or $500 \mathrm{MHz}$ for ${ }^{1} \mathrm{H}$, 100 or $125 \mathrm{MHz}$ for ${ }^{13} \mathrm{C}$, and $202 \mathrm{MHz}$ for ${ }^{31} \mathrm{P}$ using $\mathrm{D}_{2} \mathrm{O}$ as solvent. Chemical shifts for ${ }^{1} \mathrm{H}$ were reported in ppm relative to the HOD signal referenced at $\delta 4.65$ at $303 \mathrm{~K}$. For ${ }^{13} \mathrm{C}$, methanol- $d_{4}(3 \%)$ was added as the internal standard and referenced at $\delta 49.0 . \mathrm{H}_{3} \mathrm{PO}_{3}$ was referenced at $0 \mathrm{ppm}$ for ${ }^{31} \mathrm{P}$ NMR. HMBC and HMQC spectra for $\mathbf{1}$ and $\mathbf{2}$ were recorded on 400 and $750 \mathrm{MHz}$ instrument, respectively. FABMS was recorded on JEOL JMS 700 instrument in FAB mode using glycerol as matrix. HRFABMS data were measured with polyethylene glycol 400 as internal standard. The optical rotation was measured with HORIBA SEPA-300 digital polarimeter. Circular dichromism was measured with a JASCO J720 spectropolarimeter.

\section{Biological Material}

A sample of Lendenfeldia chondrodes was collected in Yap state Micronesia at depth of $6 \sim 8 \mathrm{~m}$. The sponge was formerly identified as Dysidea herbacea, however, recent study pointed out that identification of some dictyoceratid sponges including $D$. herbacea by their morphology alone is extremely difficult, and genetic analysis is necessary to draw conclusion [24]. We thus examined 5.8S, ITS-2 and 28S rDNA gene sequence of this specimen and found it was nearly identical with that of $L$. chondrodes. Detailed study on biological aspects of this sponge will be published elsewhere.

\section{Isolation}

The sponge ( $200 \mathrm{~g})$ was homogenized with equal amount of water, 2-propanol was added to precipitate macromolecules, centrifuged, and then the supernatant was concentrated to give the aqueous extract $(8.5 \mathrm{~g})$. This was separated on a Sephadex LH20 column $(5 \times 63 \mathrm{~mm})$, and the fractions which contained 1 and $\mathbf{2}(400 \sim 600 \mathrm{ml}$ eluate, $1.87 \mathrm{~g}$ ) were combined and further separated with a Biogel P-2 column $(5 \times 63 \mathrm{~mm})$. The fractions eluted between 900 and $1040 \mathrm{ml}$ were combined and further separated by anion exchange column (DE 52, $1.5 \times 14 \mathrm{~cm}$, Whatman) with successive water $(100 \mathrm{ml})$, acetic acid $(0.05 \mathrm{~N}, 200 \mathrm{ml})$ and a liner gradient with acetic acid $(0.05 \mathrm{~N}, 300 \mathrm{ml})$ ammonium acetate $(0.05 \mathrm{~N}, 300 \mathrm{ml})$. Compounds $\mathbf{1}$ and $\mathbf{2}$ were eluted with the gradient buffer between $220 \sim 290 \mathrm{ml}$ fractions. These compounds were finally purified by C30 reversed-phase column (Develosil, $1 \times 20 \mathrm{~cm}$, Nomura Chemical Co.) equipped with a refractive index detector using water as an eluent.

\section{Deoxynojirimycin-6-phosphate (1)}

Colorless amorphous solid (3.6 mg): $[\alpha]_{\mathrm{D}}^{24}+27$ (c 0.19 , $\mathrm{H}_{2} \mathrm{O}$ ); IR (KBr) v 3399, 2924, 1639, $1102 \mathrm{~cm}^{-1}$; NMR (see Table 1); HRMS (FAB) calcd for $\mathrm{C}_{6} \mathrm{H}_{15} \mathrm{NO}_{7} \mathrm{P}$ 244.0581, found $m / z 244.0566(\mathrm{M}+\mathrm{H})^{+}$.

$\mathrm{N}$-Methyl-deoxynojirimycin-6-phosphate (2)

Colorless amorphous solid $[\alpha]_{\mathrm{D}}^{24}+9.7\left(c 0.10, \mathrm{H}_{2} \mathrm{O}\right)$; IR (KBr) $v$ 3420, 2910, 1643, $1077 \mathrm{~cm}^{-1}$; ${ }^{1} \mathrm{H}$ and ${ }^{13} \mathrm{C}$ NMR (see Table 1); HRMS (FAB) calcd for $\mathrm{C}_{7} \mathrm{H}_{17} \mathrm{NO}_{7} \mathrm{P}$ 258.0737, found $m / z 258.0776(\mathrm{M}+\mathrm{H})^{+}$.

\section{Pentaacetyl Deoxynojirimycin (3)}

An authentic sample of deoxynojirimycin was treated with $\mathrm{Ac}_{2} \mathrm{O}$ in pyridine ( 2 hours, rt.). Reagents were removed under a stream of $\mathrm{N}_{2}$ to give 3. $\mathrm{CD}(\mathrm{MeOH}) \lambda$ ext $(\Delta \varepsilon)=230 \mathrm{~nm}(1.33) .{ }^{1} \mathrm{H}$ NMR $\left(\mathrm{CD}_{3} \mathrm{OD}\right) \delta 5.11(\mathrm{br} \mathrm{s}), 5.00$ (br s), 4.90 (br d, $J=13.2$ ), 4.73 (br m), 4.43 (br m), 4.31 (br m), 3.97 (brd, $J=13.2$ ), 3.80 (br d, $J=13.2$ ), 3.2 (brd), 2.14 2.03 $\left(\mathrm{CH}_{3} \times 5\right.$, broad). MS (FAB) $m / z 374(\mathrm{M}+\mathrm{H})^{+}$.

Compound $1(5 \mathrm{mg})$ was treated with $6 \mathrm{~N} \mathrm{HCl}$ at $110^{\circ} \mathrm{C}$ for 12 hours. The hydrolyzate was treated with $\mathrm{Ac}_{2} \mathrm{O}$ in pyridine as above. The product was partitioned between $\mathrm{CHCl}_{3}-\mathrm{MeOH}$ - water $(2: 1: 1)$, and the lower layer was separated by a silica gel column with $\mathrm{CHCl}_{3}-\mathrm{MeOH}(9: 1)$ to give 3 (3.0 mg): colorless amorphous solid, $\mathrm{CD}(\mathrm{MeOH})$ $\lambda \operatorname{ext}(\Delta \varepsilon)=230 \mathrm{~nm}(0.73),{ }^{1} \mathrm{H}$ NMR $\left(\mathrm{CD}_{3} \mathrm{OD}\right) \delta 5.11$ (brs), 
5.00 (br s), 4.90 (brd, $J=13.2$ ), 4.73 (br m), 4.43 (br m), 4.31 (br m), 3.97 (brd, $J=13.2$ ), 3.80 (br d, $J=13.2$ ), 3.2 (brd), $2.14 \sim 2.03$ (br singlets). HRMS (FAB) calcd for $\mathrm{C}_{16} \mathrm{H}_{24} \mathrm{NO}_{9}$ 374.1451, found $m / z \quad 374.1432(\mathrm{M}+\mathrm{H})^{+}$. Authentic and naturally derived 3 co-migrated on TLC (silica gel, $\mathrm{CHCl}_{3}-\mathrm{MeOH}, 9: 1$ ) at $\mathrm{Rf}$ value of 0.7 as a blight red spot visualized by ninhydrin.

Acknowledgements This manuscript is dedicated to the late professor Kenneth L. Rinehart. Initial identification of the sponge specimen was carried out by Dr. J. Hooper at Queensland museum, Australia. We are grateful to A. Tafileichig at Marine Resources Management Division, Department of Resources \& Development Yap State Government and M. Yasui for assistance in sample collection. We also thank Dr. K. Adachi at Marine Biotechnology Institute for assistance in NMR measurements and D. Imaizumi for assistance in isolation work. Part of this research was supported by Ministry of Education, Culture, Sports, Science and Technology (17380125).

\section{References}

1. Yagi M, Kouno T, Aoyagi Y, Murai H. The structure of moranoline, a piperidine alkaloid from Morus species. Nippin Nougei Kagaku Kaishi 50: 571-572 (1976)

2. Tan A, van den Broek L, van Boeckel S, Ploegh H, Bolscher J. Chemical modification of the glucosidase inhibitor 1deoxynojirimycin. Structure-activity relationships. J Biol Chem 266: 14504-14510 (1991)

3. Romero PA, Datema R, Schwarz RT. N-methyl-1deoxynojirimycin, a novel inhibitor of glycoprotein processing, and its effect on fowl plague virus maturation. Virology 130: 238-242 (1983)

4. Mehta A, Carrouee S, Conyers B, Jordan R, Butters T, Dwek RA, Block TM. Inhibition of hepatitis B virus DNA replication by imino sugars without the inhibition of the DNA polymerase: therapeutic implications. Hepatology 33: 1488-1495 (2001)

5. Saito T, Yamaguchi I. Effect of glycosylation and glucose trimming inhibitors on the influenza A virus glycoproteins. J Vet Med Sci 62: 575-581 (2000)

6. Karlsson GB, Butters TD, Dwek RA, Platt FM. Effects of the imino sugar $\mathrm{N}$-butyldeoxynojirimycin on the $\mathrm{N}$ glycosylation of recombinant gp120. J Biol Chem 268: 570-576 (1993)

7. Gruters RA, Neefjes JJ, Tersmette M, de Goede RE, Tulp A, Huisman HG, Miedema F, Ploegh HL. Interference with HIV-induced syncytium formation and viral infectivity by inhibitors of trimming glucosidase. Nature 330: 74-77 (1987)

8. van der Spoel AC, Jeyakumar M, Butters TD, Charlton HM, Moore HD, Dwek RA, Platt FM. Reversible infertility in male mice after oral administration of alkylated imino sugars: a nonhormonal approach to male contraception. Proc Natl Acad Sci USA 99: 17173-17178 (2002)

9. Andersson U, Smith D, Jeyakumar M, Butters TD, Borja MC, Dwek RA, Platt FM. Improved outcome of $\mathrm{N}$ butyldeoxygalactonojirimycin-mediated substrate reduction therapy in a mouse model of Sandhoff disease. Neurobiol Dis 16: 506-515 (2004)

10. Butters TD, Dwek RA, Platt FM. New therapeutics for the treatment of glycosphingolipid lysosomal storage diseases. Adv Exp Med Biol 535: 219-226 (2003)

11. Cox TM, Aerts JM, Andria G, Beck M, Belmatoug N, Bembi B, Chertkoff R, Vom Dahl S, Elstein D, Erikson A, Giralt M, Heitner R, Hollak C, Hrebicek M, Lewis S, Mehta A, Pastores GM, Rolfs A, Miranda MC, Zimran A. The role of the iminosugar $N$-butyldeoxynojirimycin (miglustat) in the management of type I (non-neuronopathic) Gaucher disease: a position statement. J Inherit Metab Dis 26: 513-526 (2003)

12. Elstein D, Hollak C, Aerts JM, van Weely S, Maas M, Cox TM, Lachmann RH, Hrebicek M, Platt FM, Butters TD, Dwek RA, Zimran A. Sustained therapeutic effects of oral miglustat (Zavesca, $N$-butyldeoxynojirimycin, OGT 918) in type I Gaucher disease. J Inherit Metab Dis 27: 757-766 (2004)

13. Jeyakumar M, Norflus F, Tifft CJ, Cortina-Borja M, Butters TD, Proia RL, Perry VH, Dwek RA, Platt FM. Enhanced survival in Sandhoff disease mice receiving a combination of substrate deprivation therapy and bone marrow transplantation. Blood 97: 327-329 (2001)

14. Jeyakumar M, Smith DA, Williams IM, Borja MC, Neville DC, Butters TD, Dwek RA, Platt FM. NSAIDs increase survival in the Sandhoff disease mouse: synergy with $\mathrm{N}$ butyldeoxynojirimycin. Ann Neurol 56: 642-649 (2004)

15. Sakai R, Kamiya H, Murata M, Shimamoto K. Dysiherbaine: A new neurotoxic amino acid from the Micronesian marine sponge Dysidea herbacea. J Am Chem Soc 119: 4112-4116 (1997)

16. Sakai R, Koike T, Sasaki M, Shimamoto K, Oiwa C, Yano A, Suzuki K, Tachibana K, Kamiya H. Isolation, structure determination, and synthesis of neodysiherbaine A, a new excitatory amino acid from a marine sponge. Org Lett 3: 1479-1482 (2001)

17. Sakai R, Oiwa C, Takaishi K, Kamiya H, Tagawa M. Dysibetaine: a New $\alpha$-disubstityted $\alpha$-amino acid derivative from the Marine Sponge Dysidea herbacea. Tetrahedron Lett 40: 6941-6944 (1999)

18. Sakai R, Suzuki K, Shimamoto K, Kamiya H. Novel betaines from a micronesian sponge Dysidea herbacea. J Org Chem 69: 1180-1185 (2004)

19. Asano N, Yamashita T, Yasuda K, Ikeda K, Kizu H, Kameda Y, Kato A, Nash RJ, Lee HS, Ryu KS. Polyhydroxylated alkaloids isolated from mulberry trees (Morus alba L.) and silkworms (Bombyx mori L.). J Agric Food Chem 49: 4208-4213 (2001)

20. Kim YM, Wang MH, Rhee HI. A novel alpha-glucosidase 
inhibitor from pine bark. Carbohydr Res 339: 715-717 (2004)

21. Stein DC, Kopec LK, Yasbin RE, Young FE. Characterization of Bacillus subtilis DSM704 and its production of 1-deoxynojirimycin. Appl Environ Microbiol 48: 280-284 (1984)

22. Shibano M, Fujimoto Y, Kushino K, Kusano G, Baba K. Biosynthesis of 1-deoxynojirimycin in Commelina communis: a difference between the microorganisms and plants. Phytochemistry 65: 2661-2665 (2004)

23. Scudder PR, Dwek RA, Rademacher TW, Jacob GS (US 5043273: Monsanto Company) Phosphorylated glycosidase inhibitor prodrugs, EP 413674, (1991)

24. Ridley CP, Bergquist PR, Harper MK, Faulkner DJ, Hooper JN, Haygood MG. Speciation and biosynthetic variation in four dictyoceratid sponges and their cyanobacterial symbiont, Oscillatoria spongeliae. Chem Biol 12: 397-406 (2005) 